\title{
DIZZINESS AND THE RISK OF FALLING IN THE ELDERLY: A LITERATURE REVIEW
}

\section{Andrea Ciorba}

Audiology and ENT Department, University Hospital of Ferrara, Ferrara, Italy

Corresponding author: Andrea Ciorba, Audiology and ENT Department, University Hospital of Ferrara, via A. Moro 8, Cona, Ferrara 44123, Italy, e-mail: andrea.ciorba@unife.it

\begin{abstract}
Slipping and falling in the elderly present an important public health problem, as falls can lead to serious injury. Falling-related costs, both health and social, are very high in western countries and increased attention is being given to the issue. Dizziness is one of the main causes of falling in the elderly. Its origin can depend on many factors, including cardiovascular/neurological disease, sensory deterioration, and vestibular dysfunction. Assessment of such patients can be tricky, requiring the presence of an otolaryngologist and/or audiologist. In terms of a therapeutic strategy, various options exist but the final solution can be very challenging, since the choice of drugs or rehabilitation program/s must consider the residual function of different systems (as well as the vestibular system) and of other medical conditions that can disturb balance.
\end{abstract}

Key words: dizziness • vertigo • elderly • older adults • risk of falls

\section{VÉRTIGO Y RIESGO DE CAÍDA EN PERSONAS MAYORES: REVISIÓN DE LITERATURA AL RESPETO}

\section{Resumen}

El tropezón y la caída de una persona de edad avanzada es un gran problema para el sistema de salud pública, ya que puede provocar unas lesiones muy serias. Los costes asociados con la caída, tanto el de la asistencia médica, como y el coste social, son muy altos en los países de Europa occidental, por lo que el problema cobra cada vez más importancia. El vértigo es una de las causas principales de la caída de una persona mayor. Son muchos los factores que pueden provocar el vértigo, entre ellos cabe mencionar las enfermedades cardiovasculares, enfermedades neurológicas, deterioro de los sentidos y del sistema vestibular. La evaluación de dichos pacientes puede resultar difícil y precisar de la presencia de un otorrinolaringólogo y/o audiólogo. En cuanto a los métodos terapéuticos, las opciones son diversas, pero la selección definitiva puede convertirse en un reto, ya que la prescripción de las medicinas adecuadas y del/de los programa(s) de rehabilitación deben tomar en cuenta el funcionamiento actual de distintos sistemas (incluyendo el sistema vestibular) y el estado de salud en otros campos, que puedan provocar la pérdida de equilibrio.

Palabras clave: vértigo • personas de edad avanzada • riesgo de caída

\section{ГОЛОВОКРУЖЕНИЕ И РИСК ПАДЕНИЙ У ПОЖИЛЫХ ЛЮДЕЙ: ОБЗОР ЛИТЕРАТУРЫ}

\section{Изложение}

Спотыкание и падение пожилого человека является большой проблемой народного здравоохранения, потому что они могут привести к серьезным травмам. Расходы на здравоохранение, а также социальные, связанные с падением являются очень высокими в западных странах. Этой проблеме придается все большее значение. Головокружение - это одна из главных причин падений пожилых людей. Множество факторов может являться причиной головокружения, в том числе сердечно-сосудистые и неврологические заболевания, ухудшения в области органов чувств, повреждения преддверного органа. Оценка таких пациентов может быть сложной, требующей присутствия отоларинголога и/или аудиолога. В отношении терапевтического метода существует множество вариантов, однако окончательный выбор бывает испытанием, потому что подбор лекарств и программы/ программ реабилитации должен учитывать существующее функционирование различных систем (а также преддверной системы) и состояние здоровья других областей, которые могут вызвать потерю равновесия.

Ключевые слова: головокружение • пожилые люди • риск падений 


\title{
ZAWROTY GLOWY I RYZYKO UPADKU U OSÓB STARSZYCH: PRZEGLĄD LITERATURY
}

\begin{abstract}
Streszczenie
Potknięcie się i upadek starszej osoby jest dużym problemem zdrowia publicznego ponieważ może prowadzić do poważnych urazów. Koszty, zarówno opieki zdrowotnej jak i społeczne, związane z upadkiem są bardzo wysokie w krajach zachodnich. Do tego problemu przywiązuje się coraz większą uwagę. Zawroty głowy są jednym z głównych powodów upadku osoby starszej. Wiele czynników może stanowić przyczynę zawrotów głowy, w tym choroby sercowo-naczyniowe i neurologiczne, pogorszenia w obrębie zmysłów, uszkodzenia narządu przedsionkowego. Ocena takich pacjentów może być trudna, wymagająca obecności otolaryngologa i/lub audiologa. Pod względem metody terapeutycznej istnieje wiele opcji ale ostateczny wybór bywa wyzwaniem, ponieważ dobór leków i programu/ów rehabilitacji musi uwzględniać istniejące funkcjonowanie różnych systemów (jak również systemu przedsionkowego) oraz stanu zdrowia w innych obszarach, które mogą powodować utratę równowagi.
\end{abstract}

Słowa kluczowe: zawroty głowy • osoby w podeszłym wieku • ryzyko upadku

\section{Backgrund}

Slips and falls in the elderly are a leading public health problem, since they can lead to serious injury. In the elderly, the increased susceptibility to falling can be related to age-related physiological changes and to a higher prevalence of comorbidities, such as cerebrovascular or neurological diseases (e.g. parkinsonism). In particular, impairment of peripheral and central vestibular function can strongly contribute to disequilibrium and falls [1-5].

Dizziness is the term used to indicate a condition that affects an individual's balance, and it is one of the main causes of falls in the elderly. Dizziness often has a multifactorial etiology. Its prevalence has been reported to increase progressively with age, with incidences $>50 \%$ in those aged $>90$ years. Women have been reported to be more frequently affected than men [1-9]. Moreover, since the population of older adults in western countries has increased over recent decades, dizziness is becoming more prevalent [1-9].

In order to evaluate the risk and the prevention strategies for falling, it is clear that understanding all the mechanisms involved in maintaining postural and dynamic stability is important. The health costs of falls in the US and in European countries are reported to be very high, and so a strategy of prevention is emerging as a desirable solution [1-5].

This paper presents a review of dizziness in the elderly based on information from PubMed published papers in the period 2004-14.

\section{Methods}

The PubMed database (http://www.ncbi.nlm.nih.gov/pubmed) was searched from 2004 up to December 2014. Fulltext articles were obtained in cases where the title, abstract, or key words suggested that the study may be eligible for this review. The search was carried out independently, and restricted to papers in English. Other papers were also identified from references in the published literature.

The medical subject heading (MeSH) terms used included: presbystasis, dizziness, elderly, older adults, risk of falls.
Table 1. Papers retrieved from a PubMed search for years 2004-14

\begin{tabular}{|c|c|}
\hline Total number of articles from PubMed search & 58 \\
\hline $\begin{array}{l}\text { Other papers from references in the published } \\
\text { literature }\end{array}$ & 18 \\
\hline Papers excluded* & 24 \\
\hline Total number of articles evaluated & 52 \\
\hline \multicolumn{2}{|c|}{$\begin{array}{l}\text { * exclusion criteria were: full text not available; manu } \\
\text { script not in English; case reports. }\end{array}$} \\
\hline \multicolumn{2}{|c|}{$\begin{array}{l}\text { The total number of articles obtained from the PubMed } \\
\text { database search was } 58 ; 18 \text { other papers were retrieved } \\
\text { from references in the published literature. A total of } 24 \\
\text { papers were excluded because the full text was not avail } \\
\text { able, the manuscript was not in English, or it was a case } \\
\text { report (see Table } 1 \text { ). }\end{array}$} \\
\hline
\end{tabular}

\section{Dizziness in the elderly: definitions and risk factors}

Control of posture and balance requires a complex continuous interaction between several systems such as neuromuscular reflexes, musculoskeletal components, sensory inputs, and visual information. All this information is then processed and integrated by the central nervous system (CNS). It has been reported that in elderly subjects the sensory systems have undergone partial deterioration and that older brains are weaker in processing capacity, memory, and attention; therefore symptoms such as disequilibrium and dizziness can easily develop [10-17]. Several authors consider persistent dizziness, resulting from deterioration/aging of the sensory systems, and the concomitant CNS processing disorders that occur with age, as a novel geriatric syndrome itself [1-9].

\section{The aging vestibular system}

A progressive loss of hair cells have been described both at the ampullary crests and at the saccule and utricle maculae within the adult inner ear. Also the remaining hair cells have been found to be affected by degenerative features such as destruction of ciliar elements or cytoplasmic 
inclusions, and this could further impair vestibular function. Degeneration of the otoconial layers and deformation of the labyrinthine walls have been described, as well as mineralization of the semicircular canal cupulae $[18,19]$. Brainstem structural changes have been observed, with a reduction in the number of neurons in the vestibular nuclei $[18,19]$. There are also reports that with increasing age there is a vermian atrophy and a decrease in the number of cerebellar Purkinje cells. Deterioration of the vascular structures of the inner ear has also been described, with reduction in the number of capillaries and thinning of the capillary walls, leading to consequent higher susceptibility to ischemic phenomena $(18,19)$.

\section{Vestibular disorders}

Several vestibular diseases, such as benign paroxysmal positional vertigo (BPPV) and acute peripheral vestibular disorders such as Meniere disease, have been reported to occur also in the elderly, thereby causing acute onset of dizziness/disequilibrium. Elderly patients who have acute unilateral hypofunction (vestibular asymmetry) complain more frequently of falling [1-5,20-24].

\section{Other factors influencing balance in the elderly}

Apart from ageing of the vestibular system and accompanying vestibular disorders, there are other multiple conditions which can contribute to worsening of dizziness in the elderly and generally impair postural and dynamic stability.

In particular, CNS disorders (e.g. cerebrovascular diseases or parkinsonism) can greatly contribute to the onset as well as to the persistence of dizziness. Although cognitive deficits, such as Alzheimer's and dementia, have been recognized as a risk factor for dizziness and falls, their role is less widely considered and appreciated. Parkinson's disease, Alzheimer's disease, and dementia are all conditions that can limit mobility, worsen balance, and predispose to falls. Also psychogenic conditions such as depressive status or anxiety disorder have been related to dizziness and chronic disequilibrium $[1-5,25,26]$.

Cardiovascular conditions, such as orthostatic hypotension or atrial fibrillation, or even hypertension, can contribute to accidental falls by affecting the cerebral vascular flow $[27,28]$.

Several types of medications also produce dizziness as a side-effect. They include chemotherapeutic agents, several antibiotics (such as aminoglycosides), antidepressants, and anxiolytics. Medication can cause dizziness mainly through anticholinergic effects (different from the aminoglycosides which may cause direct ototoxic damage). Psychotropic medications including antidepressants, drugs used to treat bipolar conditions, anxiolytics/hypnotics, drugs used in dementia, and antipsychotics, all of which have been shown to increase the risk of falling $[1-5,29,30]$.

Moreover, it is believed that persistent dizziness is underlain by the joint action of more than a single disease. In particular, visual disorders, CNS disease, as well as vestibular disease, can increase the symptomatology and be responsible for falls [1-5].

\section{Dizziness and falling in the elderly}

Falls have been defined as "an unexpected event in which the subjects come to rest on the ground, floor, or lower level" by the Prevention of Falls Network Earth (ProFaNE) (www.profane.co). The incidence of falling has been reported to range between 30 and $60 \%$ per year in older adults, with 10-20\% suffering consequent injury (e.g. femur fracture), hospitalization, and/or even death. Falls can therefore be considered to increase mortality rates as well as morbidity rates (e.g. requiring long recoveries perhaps in a nursing home).

Dizziness is one of the major factors increasing the risk of a fall. Falls are usually due to multiple factors, and a single specific cause is usually difficult to identify [1-5]. In the literature, the risk factors for falls have generally been divided into personal factors and environmental factors. Personal factors include characteristics of the individual such as age, functional abilities, chronic disease, and balance impairment. Other personal issues can also be involved, such as concomitant pathologies (e.g. osteoarthritis) or slower protective reflexes. Environmental factors refer to dangers such as poor fitting footwear, slippery floor, lack of stair grab bars, unstable furniture, and poor lighting [31]. Footwear in particular can interfere with postural stability and strongly affect the incidence of accidental falls. Some researchers speculate that it might be possible to reduce the rate of falls by ameliorating environmental risk factors $[1-5,32,32,34]$.

\section{Diagnostic and therapeutic strategies}

Evaluation as well as treatment of dizziness in the elderly can be crucial in preventing falls. However, assessing the fall-prone patient is always tricky. For a patient who has already fallen, it is important to acquire all the information about the symptoms relevant to the fall, including witness accounts if available, with the aim of identifying specific factor/s contributing to the event. The dizzy patient who is at risk for falls can be evaluated by different specialists with the aim of assessing all the different risk factors for falling; formal balance assessment protocols, such as the Tinetti scale, can be used [1-5]. Since it is not possible to use the same diagnostic and therapeutic scheme for all the different forms of dizziness, each patient should be carefully evaluated. If possible, the cause of falls should be identified and the cause of dizziness corrected, which together will reduce the risk of falls $[1-5,19]$. For CNS disorders or cardiovascular disease, identification and therapy must be carried out by competent specialist.

The otolaryngologist or audiologist should focus on the diagnosis and treatment of vestibular system disorders. The correction of sensory deficits and the treatment of degenerative events associated with vertigo/dizziness should be the goal of therapy if possible. The aim should be to stabilize peripheral sensory changes and create central vestibular compensation. This can be done by using drugs and rehabilitation exercises (the latter can be administrated after having considered specific patient conditions) $[1-5,19]$.

Although the therapeutic principles used to treat dizzy older adults are similar to those used for younger adults, 
there are differences that should be considered. In particular, when choosing a therapy, it is necessary to consider the residual function of other systems (e.g. liver and kidney) and the presence of other medical conditions that may be aggravated by adverse reaction or side-effects of drugs. Rehabilitation programs in the elderly should also be selected based on general physical condition. Physical rehabilitation manoeuvers or certain exercises can be administrated if the specific clinical condition of the patient has been evaluated (such as a degenerative articular process or musculoskeletal disease). If irreversible problems exist (e.g. neurological diseases such as hemiparesis or ataxia), alternative rehabilitative strategies, tailored to a specific subject and condition, should be developed.

Programs aiming to (i) increase muscular strength and endurance, and (ii) eliminate environmental risks, should be proposed in order to achieve the best outcome in terms of reducing dizziness and therefore risk of falls [1-5,19,35-44]. For example, in a vestibular rehabilitation protocol, patients should be provided with a series of tasks to perform that require them to use their eyes while moving their head, and possibly when their body is moving too. Vestibular rehabilitation has been shown to improve several aspects of balance, including vestibulo-visual interaction during head movements, static and dynamic postural stability under conditions of reduced sensory input, and lessened sensitivity to head movements [1-5,37-44].
The most difficult task is to reduce the risk of falling in those with numerous and/or permanent causes (e.g. neurological diseases such as hemiparesis or ataxia). It is then always advisable to reduce all the other possible risk factors for falling and design a safe environment, especially at home $[1-5,37]$.

\section{Conclusions}

Attention to problems related to dizziness and to the risk of falling in the elderly is growing, as evidenced by (i) the growing number of papers in the field, particularly in the last decade; (ii) rising interest about the wellbeing of the elderly patient; and (iii) the significant gains in life expectancy in western countries.

As discussed, the goal of reducing the risk of falling requires an interdisciplinary approach. Physical activity and rehabilitation techniques must be encouraged, as they provide a physiological route for functional recovery which can avoid immobilization and encourage an active state. Rehabilitation strategies have improved of late; however, in the future a further step would be to design specific protocols for subjects with particular risk factors or diseases, so-called tailored rehabilitative therapy.

\section{References:}

1. Rubenstein LZ. Falls in older people: epidemiology, risk factors and strategies for prevention. Age Ageing, 2006; 35: 37-41.

2. Ambrose AF, Paul G, Hausdorff JM. Risk factors for falls among older adults: a review of the literature. Maturitas, 2013; 75(1): 51-61.

3. Walther LE, Rogowski M, Schaaf H, Hörmann K, Löhler J. Falls and dizziness in the elderly. Otolaryngol Pol, 2010; 64(6): 354-7.

4. Walther LE, Kleeberg J, Rejmanowski G, Hänsel J, Lundershausen D, Hörmann $\mathrm{K}$ et al. [Falls and fall risk factors: are they relevant in ENT outpatient medical care?] HNO, 2012; 60(5): 446, 448-56 [in German]

5. Nanda A. Chronic dizziness in older persons. Med Health Rhode Is, 2007; 90(9): 291-3.

6. Vassallo M, Azeem T, Pirwani MF, Sharma JC, Allen SC. An epidemiological study of falls on integrated general medical wards. Int J Clinical Prac, 2000; 54: 654-7.

7. Bates DW, Pruess K, Souney P, Platt R. Serious falls in hospitalized patients: correlates and resource utilization. Am J Med, 1995; 99: 137-43.

8. Tinetti ME, Williams TF, Mayewski R. Fall risk index for elderly patients based on number of chronic disabilities. Am J Med, 1986; 80: 429-34.

9. Sartini M, Cristina ML, Spagnolo AM et al. The epidemiology of domestic injurious falls in a community dwelling elderly population: an outgrowing economic burden. Eur J Public Health, 2009; 20: 604-6.

10. Ueneri A, Polat $\mathrm{S}$. Vertigo, dizziness and imbalance in the elderly. J Laryngol Otol, 2008; 122: 466-9.

11. Horak FB, Shupert CL. Components of postural dyscontrol in the elderly: a review. Neurobiol Ageing, 1989; 10: 727-38.
12. Kerber KA, Enrietto JA, Jacobson KM, Baloh RW. Disequilibrium in older people: a prospective study. Neurology, 1998; 51: $574-80$.

13. Maki BE, McIlroy WE, Fernie GR. Change-in-support reactions for balance recovery. IEEE Eng Med Biol Mag, 2003; 22: $20-6$.

14. Teasdale N, Stelmach GE, Bard C, Fleury M. Posture and elderly persons: deficit in the central integrative mechanisms. In: Wollacott M, Horak F, eds. Posture and Gait: Control Mechanisms. Portland, Oregon: University of Oregon, 1992; 203-7.

15. Lundin-Olsson L, Nyberg L, Gustafson Y. 'Stops walking when talking' as a predictor of falls in elderly people, Lancet, 1997; 349: 617

16. Steinman BA, Allen SM. Self-reported vision impairment and its contribution to disability among older adults. J Aging Health, 2012; 24: 307-22.

17. Bovo R, Faccioli C, Martini A. Dizziness in the elderly. Hear Balance Comm, 2014; 12: 54-65.

18. Rosenhall U. Degenerative patterns in the aging human vestibular neuro-epithelia. Acta Otolaryngol, 1973: 76: 208-20.

19. Martini A, Calabrese G. I disturbi dell'equilibrio. In Il Paziente Anziano in ORL a Cura di C. Calearo. Pacini Editore, Pisa, 1983 [in Italian]

20. Di Fabio RP, Emasithi A, Greany JF, Paul S. Suppression of the vertical vestibuloocular reflex in older persons at risk of falling. Acta Otolaryngol, 2001; 121: 707-14.

21. Kristinsdottir EK, Nordell E, Jarnlo GB, Tjader A, Thorngren KG, Magnusson M. Observation of vestibular asymmetry in a majority of patients over 50 years with fall-related wrist fractures. Acta Oto-Laryngol, 2001; 121: 481-5. 
22. Honaker JA. Shepard NT. Use of the dynamic visual acuity test as a screener for community-dwelling older adults who fall. J Vestib Res, 2011; 21(5): 267-76.

23. Baloh RW, Enrietto J, Jacobson KM, Lin A. Age-related changes in vestibular function: a longitudinal study. Ann NY Acad Sci, 2001; 942: 210-9.

24. Whitney SL, Hudak MT, Marchetti GF. The dynamic gait index relates to self reported fall history in individuals with vestibular dysfunction. J Vestib Res, 2000; 10: 99-105.

25. Gleason CE, Gangon RE, Fischer BL, Mahoney JE. Increased risk for falling associated with subtle cognitive impairments, secondary analysis of a randomized clinical trial. Dement Geriatr Cogn Dis, 2009; 27: 557-63.

26. Muir SW, Gopaul K, Montero Odasso MM. The role of cognitive impairment in fall risk among older adults: a systematic review and meta-analysis. Age Ageing, 2012; 41(3): 299-308.

27. Lipsitz LA. Orthostatic hypo-tension in the elderly. N Engl J Med, 1989; 321: 952-7.

28. Hausdorff JM, Herman T, Baltadjieva R, Gurevich T, Giladi N. Balance and gait in older adults with systemic hypertension. Am J Cardiol, 2003; 91(5): 643-5.

29. Hartikainen S, Lonnroos E, Louhivuori K. Medication as a risk factor for falls: critical systematic review. J Gerontol Med Sci, 2007; 62(10): 1172-81.

30. Woolcott JC, Richardson KJ, Wiens MO et al. Meta-analysis of the impact of 9 medication classes on falls in elderly persons. Arch Intern Med, 2009; 169(21): 1952-60.

31. AGS/BGS/AAOS Panel on Falls Prevention. Guideline for the prevention of falls in older persons. J Am Geriatr Soc, 2001; 49: 664-72.

32. Gillespie LD, Gillespie WJ, Robertson MC, Lamb SE, Cumming RG, Rowe BH. Interventions for preventing falls in elderly people. Cochrane Database Syst Rev, 2003; 4: CD000340.

33. Menz HB, Morris ME, Lord SR. Footwear characteristics and risk of indoor and outdoor falls in older people. Gerontol, 2006; 52(3): 174-80.
34. Axer H, Axer M, Sauer H, Witte OW, Hagemann G. Falls and gait disorders in geriatric neurology. Clin Neurol Neurosurg, 2010; 112: 265-74.

35. Rubenstein LZ, Josephson KR, Trueblood PR. Effects of a group exercise program on strength, mobility, and falls among fallprone elderly men. J Gerontol A Biol Sci Med Sci, 2000; 55: M317-21.

36. Province MA, Hadley EC, Hornbrook MC et al. The effects of exercise on falls in elderly patients: a preplanned meta-analysis of the FICSIT trials. JAMA, 1995; 273: 1341-7.

37. Herdman SJ, Schubert MC, Tusa RJ. Strategies for balance rehabilitation: fall risk and treatment. Ann NY Acad Sci, 2001; 942: 394-412.

38. Horning E, Gorman S. Vestibular rehabilitation decreases fall risk and improves gaze stability for an older individual with unilateral vestibular hypofunction. J Geriatr Phys Ther, 2007; 30(3): 121-7.

39. Criter RE, Honaker JA. Falls in the audiology clinic: a pilot study. J Am Acad Audiol, 2013; 24(10): 1001-5.

40. Shaw BH, Claydon VE. The relationship between orthostatic hypotension and falling in older adults. Clin Auton Res, 2014; 24(1): 3-13.

41. Boelens C, Hekman EE, Verkerke GJ. Risk factors for falls of older citizens. Technol Health Care, 2013; 21(5): 521-33.

42. Dros J, Maarsingh OR, Beem L, van der Horst HE, ter Riet G, Schellevis FG et al. Functional prognosis of dizziness in older adults in primary care: a prospective cohort study. J Am Geriatr Soc, 2012; 60(12): 2263-9.

43. Furman JM, Raz Y, Whitney SL. Geriatric vestibulopathy assessment and management. Curr Opin Otolaryngol Head Neck Surg, 2010; 18(5): 386-91.

44. Deandrea S, Lucenteforte E, Bravi F, Foschi R, La Vecchia C, Negri E. Risk factors for falls in community-dwelling older people: a systematic review and meta-analysis. Epidemiology, 2010; 21(5): 658-68. 